\title{
PENGARUH KONSEP DIRI TERHADAP PERILAKU KONSUMTIF PEMBELIAN PRODUK KOSMETIK PADA WANITA DEWASA AWAL
}

\author{
Cecilia Octaviani ${ }^{1}$ dan Sandi Kartasasmita $^{2}$ \\ ${ }^{1}$ Fakultas Psikologi, Universitas Tarumanagara \\ Email: ceciliaoctaviani@gmail.com \\ ${ }^{2}$ Staf Pengajar Fakultas Psikologi, Universitas Tarumanagara \\ Email: seinama2003@yahoo.com
}

\begin{abstract}
ABSTRAK
Penelitian ini memiliki tujuan untuk mengetahui pengaruh antara konsep diri dengan perilaku konsumtif pembelilan produk kosmetik pada wanita dewasa awal. Konsep diri dalam penelitian ini berdasarkan teori dari William H. Fitts (dalam Agustiarini, 2006) sedangkan perilaku konsumtif berdasarkan teori dari Sumartono (2002). Penelitian ini melibatkan 385 responden berjenis kelamin wanita dalam rentang usia 18 hingga 40 tahun, yang berdomisili di Jakarta. Penyebaran data dilakukan melalui kuesioner baik secara manual dan online. Pengolahan data dilakukan menggunakan bantuan program SPSS for Windows versi 16.0. Hasil dari penelitian ini adalah tidak terdapat pengaruh yang signifikan dari konsep diri terhadap perilaku konsumtif pembelian kosmetik pada wanita dewasa awal di Jakarta, dengan nilai $R=0.081$ dan $R^{2}=0.006$. Nilai $R^{2}=0.006$ mengandung pengertian bahwa hanya terdapat $0.6 \%$ sumbangan pengaruh konsep diri terhadap perilaku konsumtif, sedangkan sisanya sebesar $99.4 \%$ dipengaruhi oleh faktor-faktor lainnya.
\end{abstract}

Kata kunci: perilaku konsumtif, konsep diri, kosmetik, wanita dewasa awal

\section{PENDAHULUAN}

Latar BelakangManusia memiliki berbagai macam kebutuhan, yang tersusun sesuai dengan tolok ukurnya, dari yang bersifat pokok atau primer, seperti sandang, makan, papan, hingga kebutuhan lainnya yaitu sekunder dan tersier, yang pemenuhannya bersifat menunjang kebutuhan primer (Ahman, 2007). Berbagai macam kebutuhan yang ada, dapat dipenuhi dengan proses membeli produk atau jasa yang diinginkan. Namun, kemajuan teknologi dalam bidang media massa ditambah dengan menjamurnya mall-mall membawa perubahan dalam kehidupan masyarakat, yang secara tidak sadar mempengaruhi cara pandang individu, yang kemudian berdampak terhadap perilaku membeli seseorang (Ustadiyanto \& Ariani, 2001).

Perilaku membeli awalnya difungsikan untuk memenuhi kebutuhan baik yang bersifat primer maupun sekunder. Seiring dengan bertambahnya jumlah dan variasi produk, kini semakin mengubah proses konsumsi ke budaya konsumtif-(Sumartono, 2002). Sumartono (2002) mendeskripsikan bahwa terjadi perubahan dalam proses membeli suatu produk, yang kini beralih dari yang bersifat kebutuhan (need) menjadi keinginan (want). Lubis (dalam Sumartono, 2002) mendefinisikan perlaku konsumtif sebagai sebuah perilaku yang tidak lagi didasarkan pada pertimbangan yang rasional, melainkan karena keinginan yang sudah mencapai taraf tidak rasional lagi.

Salah satu kebutuhan utama tiap masyarakat adalah menggunakan pakaian, selain pangan dan papan. Seiring dengan perkembangan zaman, fungsi pakaian berubah dari pelindung tubuh, menjadi gaya hidup dan tren (Adiputra \& Moningka, 2012). Tidak hanya pakaian yang telah berubah fungsi karena perkembangan zaman di tahun belakangan ini, terdapat pula kebutuhan lainnya yang bersifat menunjang tren dan gaya hidup, yaitu kebutuhan untuk mempercantik penampilan diri, salah satunya adalah dengan penggunaan alat kosmetik.

Perkembangan industri kosmetik Indonesia dapat dikategorikan tergolong pesat dan signifikan. Hal ini terlihat dari peningkatan penjualan kosmetik pada 2012 sebanyak $14 \%$ menjadi Rp 9,76 triliun dari sebelumnya Rp 8,5 triliun, berdasarkan data Kementerian Perindustrian (Admin, 2013). Masyarakat perkotaan di Indonesia juga didapati cenderung menggunakan lebih dari satu 
merk kosmetik yang berbeda untuk mempercantik diri mereka. Survei yang dilakukan Nielsen Indonesia tentang Pasar Kosmetik Indonesia Menjanjikan tahun 2013 mengungkapkan, terjadi peningkatan pembelian lebih dari satu merek yang awalnya $27,1 \%$ menjadi $30,2 \%$, begitu juga mereka yang membeli lebih dari tiga merek berbeda meningkat dari $12,4 \%$ menjadi $15,9 \%$ (Rostanti, 2013).

Beberapa saat yang lalu tepatnya di pertengahan bulan Juli 2014, sebuah cosmetics store S membuka branch pertamanya di Indonesia, dan berhasil menggiring ribuan orang untuk pergi ke sebuah pusat perbelanjaan di Jakarta. Bahkan, banyak juga yang rela mengantri dari subuh untuk menjadi orang-orang pertama yang membeli produk dari cosmetics store $\mathrm{S}$ tersebut $(\mathrm{G}, 2014)$. Dari fenomena ini, dapat terlihat bahwa kosmetik pada tahun-tahun belakangan ini menjadi minat yang berdampak pada pembelian produk kosmetik yang semakin meningkat, khususnya pada wanita.

Kosmetik didefinisikan sebagai sediaan atau paduan bahan yang untuk digunakan pada bagian luar badan, menambah daya tarik, mengubah penampakan, dan melindungi supaya tetap dalam keadaan baik (Iswari, 2007). Fungsi produk kosmetik yang beragam didukung oleh terus diciptakannya inovasi-inovasi baru baik dalam desain packaging maupun formulasi produk yang ditawarkan dari berbagai varietas merek produk. Sehingga, tidak mengherankan jika masyarakat tertarik untuk memilikinya.

Awalnya, kosmetik yang difungsikan sebagai kebutuhan sekunder bagi konsumennya, seakan beralih menjadi sebuah kebutuhan yang sangat penting. Hal ini didasari dari keinginan para wanita yang ingin cantik sempurna dalam setiap kesempatan. Para konsumennya berasal dari beragam tingkat usia. Para wanita dewasa muda menjadi sasaran utama konsumen penjualan produk, khususnya kosmetik, karena sebagai individu, dewasa muda sudah memikul tanggung jawabnya sendiri, sehingga keputusan membeli sepenuhnya bergantung kepada diri individu, yang banyak berujung kepada perilaku konsumtif, dan golongan usia inilah yang paling banyak melakukan pembelian produk kosmetik (Fazriyanti, 2012). Dibandingkan laki-laki, wanita jauh lebih cenderung untuk membeli bukan berdasarkan kebutuhan, menjadikan kegiatan berbelanja sebagai metode perayaan, membeli barang tanpa perencanaan dan sesering mungkin (Frankel, dalam Astuti, 2013).

Pembentukan perilaku konsumtif dan keputusan untuk membeli suatu produk, secara luas dapat dikaitkan dari dua faktor yang dimana saling berhubungan, yaitu faktor internal dan faktor eksternal (Sumartono, 2002). Faktor internal dalam diri seseorang mencakup self-esteem, konsep diri, motivasi, harga diri, dan proses belajar orang yang bersangkutan. Faktor eksternal mencakup teman sebaya dan masyarakat.

Konsep diri menjadi sebuah hal yang mempengaruhi keputusan membeli dan perilaku konsumtif. Konsep diri dapat didefinisikan sebagai sarana individu dalam memperoleh gambaran dirinya secara utuh (Brooks, dalam Rakhmat, 2005). Konsep diri terdiri atas gabungan dari beberapa komponen, antara lain citra diri dan ideal diri. Citra diri adalah persepsi dan perasaan tentang ukuran dan bentuk tubuh, fungsi, penampilan dan potensi tubuh (Keliat, 1992). Individu dengan citra diri yang berkembang secara baik akan menilai dirinya secara realistis dan dapat melakukan penerimaan diri. Lain halnya dengan individu yang memiliki citra diri yang negatif, akan selalu melihat gambaran dirinya sebagai hal yang buruk, dan melakukan berbagai cara untuk 'memperbaiki' tubuh yang dianggapnya kurang baik. Pola pikir mengenai citra diri negatif ini 
akan mengarahkan individu ke perilaku membeli produk kosmetik yang fungsinya menutupi kekurangan ataupun mempercantik diri.

Diri ideal adalah persepsi individu tentang bagaimana ia harus berperilaku berdasarkan standar, tujuan atau penilaian personal tertentu (Stuart \& Sundeen, 1998). Diri ideal dipengaruhi oleh norma masyarakat, dan harapan serta tuntutan dari orang terdekat (Potter \& Perry, 2005). Apabila diri ideal yang ditetapkan individu sesuai dengan citra diri yang dimilikinya, individu tidak merasa kesulitan dalam melakukan penerimaan diri (Wong, Hockenberry-Eaton, Wilson, Winkelstein, \& Schwartz, 2002).

Citra diri dan diri ideal membentuk suatu kesatuan persepsi, yang dinamakan sebagai konsep diri. Terdapat dua jenis konsep diri, yaitu konsep diri positif dan konsep diri negatif. Individu dengan konsep diri negatif akan memandang dirinya selalu tidak mampu dan gagal, dan mempunyai pandangan negatif terhadap kehidupannya. Sebaliknya, individu yang memiliki konsep diri positif akan memiliki pandangan yang lebih menyenangkan akan dirinya sendiri. Individu yang memiliki konsep diri positif akan mempunyai penerimaan terhadap dirinya apa adanya, yang membuat individu tidak mudah terpengaruh dalam mengonsumsi kosmetik wajah untuk menutupi kekurangan, bisa mengevaluasi mana yang benar-benar menjadi kebutuhan, dan mana yang sekedar untuk penampilan.

Berdasarkan uraian fenomena diatas, penulis ingin lebih jauh lagi membahas dan mengetahui bagaimana hubungan antara konsep diri dan perilaku konsumtif pada produk kosmetik, yang dilakukan para individu wanita usia dewasa awal.

\section{Rumusan Masalah}

Apakah terdapat pengaruh konsep diri terhadap perilaku konsumtif produk kosmetik pada wanita dewasa awal?

\section{Tujuan Penelitian}

Mengetahui pengaruh konsep diri terhadap perilaku konsumtif produk kosmetik pada wanita dewasa awal.

\section{Hipotesis Penelitian}

Terdapat pengaruh negatif antara konsep diri dan perilaku konsumtif terhadap produk kosmetik.

Semakin tinggi dan baik konsep diri pada wanita dewasa muda, maka semakin rendah perilaku konsumtif individu tersebut terhadap produk kosmetik.

Semakin rendah konsep diri pada wanita dewasa muda, maka semakin tinggi perilaku konsumtif individu terhadap produk kosmetik.

\section{METODE PENELITIAN}

\section{Partisipan penelitian}

Subyek dalam penelitian ini adalah para wanita dewasa awal yang berusia 21-45 tahun di Jakarta yang jumlah populasinya diperkirakan sekitar 4 juta jiwa. Kriteria sampel yang dipilih untuk menjadi subyek adalah wanita dewasa awal yang berusia 20-40 tahun berjumlah 385 orang. Teknik sampling yang digunakan adalah nonprobability sampling dengan sampling convenient. Convenient sampling adalah teknik penentuan sampel yang berdasarkan kebetulan, yaitu siapa 
saja yang secara kebetulan bertemu dengan peneliti dapat digunakan sebagai sampel, bila dipandang orang yang kebetulan ditemui itu cocok sebagai sumber data.

\section{Jenis penelitian}

Penelitian ini dilakukan dengan pendekatan kuantitatif dengan jenis penelitian regresi untuk menjawab semua permasalahan dalam penelitian ini. Penelitian ini dilakukan untuk mengembangkan pemahaman, untuk membantu mengerti dan menginterpretasikan pengaruh konsep diri terhadap perilaku konsumtif pembelian produk kosmetik pada wanita dewasa awal. Dalam penelitian ini, akan dilakukan pembagian kuesioner kepada subyek.

\section{Alat ukur}

Pemerolehan data yang digunakan dalam penelitian ini terdiri dari 3 bagian. Bagian pertama berisi pertanyaan data kontrol seperti inisial, jenis kelamin, usia, jenis pekerjaan yang sedang ditekuni, penghasilan atau uang saku per bulan, dan pengeluaran rata-rata per bulannya. Bagian kedua berisi skala konsep diri Tennessee Self Concept Scale oleh Fitts (1971) yang dimodifikasi oleh Lorenz (2002) dengan jumlah 70 pernyataan positif dan negatif, yang terbagi dalam dua dimensi besar, yaitu dimensi internal yang didalamnya terdapat bagian diri identitas, diri perilaku, dan diri penilai; dan dimensi eksternal yang didalamnya terdapat bagian konsep diri fisik, konsep diri moral etik, konsep diri pribadi, konsep diri keluarga, dan konsep diri sosial. Skala 1 - 4 digunakan dalam kuesioner ini dengan asumsi semakin tinggi nilai jawaban, semakin besar konsep diri responden.

Bagian ketiga berisi skala perilaku konsumtif oleh Sumartono (2002) berjumlah 82 pernyataan positif dan negatif menggunakan skala 1 - 5, dengan asumsi semakin tinggi nilai jawaban, semakin tinggi perilaku konsumtif responden. Pengujian dan analisis data dalam penelitian ini menggunakan analisis regresi yang dihitung dengan bantuan program SPSS for Windows versi 16.

\section{HASIL DAN PEMBAHASAN}

Berdasarkan hasil uji regresi linear, diperoleh hasil bahwa konsep diri tidak memiliki pengaruh yang signifikan terhadap perilaku konsumtif pembelian kosmetik dengan nilai $\mathrm{R}=0.081$ dan $\mathrm{R}^{2}$ $=0.006$. Nilai $\mathrm{R}^{2}=0.006$ mengandung pengertian bahwa hanya terdapat $0.6 \%$ sumbangan pengaruh konsep diri terhadap perilaku konsumtif pembelian kosmetik, sedangkan sisanya sebesar $99.4 \%$ dipengaruhi oleh faktor-faktor lainnya. Dalam uji regresi ini juga diperlihatkan nilai $\mathrm{t}=1.582$ dan nilai $p=0.115>0.01$. Hal ini menunjukkan bahwa $\mathrm{H}_{0}$ diterima dan $\mathrm{H}_{1}$ penelitian ditolak, sehingga dapat diambil kesimpulan, tidak terdapat pengaruh yang signifikan dari konsep diri terhadap perilaku konsumtif pembelian kosmetik pada wanita dewasa awal.

\section{KESIMPULAN, SARAN, DAN DISKUSI \\ Kesimpulan}

Berdasarkan penelitian yang dilakukan, diperolah hasil bahwa tidak terdapat pengaruh yang signifikan dari konsep diri terhadap perilaku konsumtif pembelian kosmetik pada wanita dewasa awal. Dengan nilai $\mathrm{R}=0.081$ dan $\mathrm{R}^{2}=0.006$. Nilai $\mathrm{R}^{2}=0.006$ mengandung pengertian bahwa hanya terdapat $0.6 \%$ sumbangan pengaruh konsep diri terhadap perilaku konsumtif pembelian kosmetik, sedangkan sisanya sebesar $99.4 \%$ dipengaruhi oleh faktor-faktor lainnya.

\section{Diskusi}

Berdasarkan hasil analisis data, menujukkan tidak terdapat pengaruh yang signifikan dari konsep diri terhadap perilaku konsumtif pembelian kosmetik pada wanita dewasa awal. Hasil penelitian 
ini hanya sesuai untuk faktor eksternal, sedangkan faktor internal yang salah satunya adalah konsep diri, tidak berkaitan. awal yang diambil dari teori perilaku konsumtif dari Sumartono (2002). Sumartono (2002) menyebutkan terdapat dua faktor yang mempengaruhi keputusan membeli seseorang dan bagaimana individu memutuskan untuk berperilaku konsumtif, antara lain faktor eksternal dan faktor internal. Faktor eksternal berhubungan dengan kebudayaan, keluarga, kelompok sosial, referensi, dan kelas sosial. Sedangkan terdapat juga faktor internal, terdiri dari motivasi, pengamatan, proses belajar, kepribadian, dan konsep diri. Konsep diri yang peneliti pilih untuk menjadi variabel bebas (IV) penelitian untuk dilihat pengaruhnya terhadap perilaku konsumtif pembelian kosmetik, nyatanya tidak memiliki pengaruh yang cukup signifikan terhadap perilaku konsumtif pembelian kosmetik, hanya sebesar $0.6 \%$, sedangkan 99.4\% sisanya dipengaruhi oleh faktor-faktor lainnya.

Namun, hasil penelitian ini senada dengan hasil penelitian Gumulya dan Widiastuti (2013), yang juga melihat pengaruh konsep diri terhadap perilaku konsumtif, dengan wilayah subyek yang lebih kecil, yaitu mahasiswa Universitas Esa Unggul Jakarta. Gumulya dan Widiastuti (2013) menghasilkan kesimpulan bahwa hanya terdapat $0.6 \%$ sumbangan konsep diri terhadap perilaku konsumtif, dengan $p=0.309$ yang memiliki pengertian $\mathrm{H} 1$ ditolak, dan tidak terdapat pengaruh yang signifikan dari konsep diri terhadap perilaku konsumtif mahasiswa Universitas Esa Unggul.

Berdasarkan hasil analisis data, sebagian besar responden yang tercakup dalam penelitian ini (68.6\%) merupakan individu dengan konsep diri netral, 16.1\% dengan konsep diri positif, dan hanya sebesar $10.4 \%$ bagian dari keseluruhan responden yang memiliki konsep diri negatif. Fitts (1971) mendefinisikan konsep diri sebagai cara individu memandang dirinya sendiri dalam berinteraksi dengan orang lain atau lingkungan sekitar, yang kemudian akan mempengaruhi tingkah laku individu yang bersangkutan. Responden yang tercakup dalam kategorisasi konsep diri rendah dapat diartikan bahwa mereka tidak nyaman terhadap dirinya, terhadap bagaimana ia berperilaku, dan perasaan-perasaan negatif lainnya terhadap dirinya sendiri maupun terhadap orang lain. Hal tersebut dapat terlihat dari pemilihan item-item pernyataan seperti penampilan fisik yang kurang menarik, kesulitan bergaul dalam lingkungan, merasa tidak berguna, bodoh, kesulitan bertanggung jawab, dan lainnya. Pemilihan item-item tersebut menampilkan ketidaknyamanan dan ketidakpuasan responden terhadap dirinya sendiri. Hal ini sesuai dengan pernyataan Hurlock (Calhoun \& Acocella, dalam Purbasari \& Kartasasmita, 2008), yang menyebutkan bahwa seseorang yang memiliki konsep diri negatif mengembangkan perasaan tidak mampu dan rendah diri.

Sementara itu, 16.1\% responden dengan konsep diri tinggi, dapat dikatakan memiliki penerimaan diri dan kepuasan terhadap diri yang cukup, sehingga item-item pernyataan positif mengenai diri dapat dijawab dengan baik. Item-item positif yang dimaksudkan antara lain merasa nyaman terhadap diri sendiri, mudah bersosialisasi, tidak suka berbohong, memperlakukan orang tua dengan sebaik-baiknya, dan lainnya. Chodorkoff (dalam Purbasari \& Kartasasmita, 2008) menyatakan bahwa konsep diri positif bersifat stabil dan bervariasi, sehingga orang dengan konsep diri positif dapat mengerti dan menerima fakta berbeda tentang diri.

Berdasarkan analisis data yang telah dilakukan, sebagian besar responden (68.6\%) adalah individu dengan perilaku konsumtif pembelian kosmetik sedang, atau rata-rata. Terdapat $16.4 \%$ responden dengan perilaku konsumtif pembelian kosmetik yang tinggi, dan $15.1 \%$ dari keseluruhan responden dengan perilaku konsumtif pembelian kosmetik yang rendah. Perilaku konsumtif melekat pada seseorang apabila orang tersebut membeli produk diluar kebutuhan 
rasional, dan pembelian tidak lagi didasarkan pada faktor kebutuhan (need), melainkan karena faktor keinginan (want) (Sumartono, 2002). Dapat diartikan bahwa responden dengan kategorisasi perilaku konsumtif yang rendah melakukan pembelian didasarkan oleh faktor kebutuhan dan pertimbangan rasional. Item-item yang terpilih oleh responden dengan perilaku konsumtif yang rendah antara lain hanya membeli 1 merek produk dengan kegunaan atau fungsi yang sama, tidak melakukan pembelian diluar kebutuhan, tidak melakukan pembelian yang tidak direncanakan, tidak tertarik kepada kosmetik yang menarik hanya secara bungkus/penampilannya, tidak melakukan pembelian demi mendapatkan hadiah, dan lainnya.

Sedangkan pada $16.4 \%$ responden dengan perilaku konsumtif dapat diartikan melakukan pembelian berdasarkan faktor keinginan dan diluar batas pemikiran rasional. Item-item yang terpilih antara lain melakukan pembelian produk yang sedang discount, memiliki beberapa merek produk yang berbeda pada fungsi produk yang sama, sering bepergian ke mall yang baru, dan lainnya. Hal ini sesuai dengan 8 indikator perilaku konsumtif oleh Sumartono (2002).

Dari analisis gambaran konsep diri dan perilaku konsumtif pembelian kosmetik yang telah dilakukan, dapat terlihat bahwa 50.9\% dari keseluruhan responden merupakan individu dengan konsep diri netral dan perilaku konsumtif pembelian kosmetik sedang. Hal tersebut menjadi salah satu aspek mengapa penelitian ini kurang dapat menggambarkan pengaruh konsep diri terhadap perilaku konsumtif pembelian kosmetik pada wanita dewasa awal di Jakarta, sesuai dengan teori Sumartono (2002) yang menyebutkan faktor internal salah satunya konsep diri merupakan salah satu faktor yang mempengaruhi perilaku konsumtif individu.

\section{Saran}

\section{Saran teoretis}

Penelitian ini diharapkan dapat memberikan sumbangan informasi secara luas dan jelas bagi perkembangan ilmu psikologi, khususnya pada Psikologi Wanita dan Psikologi Perkembangan. Saran bagi peneliti sendiri yaitu peneliti semakin menyadari bahwa individu dengan konsep diri yang tinggi dapat merasakan kenyamanan pada dirinya, sehingga penerimaan diri dapat dilakukan, dengan ataupun tanpa kosmetik dan barang-barang yang pembeliannya bersifat konsumtif.

Saran dari peneliti untuk bidang Psikologi Wanita dan Psikologi Perkembangan adalah untuk menekankan bahwa gambaran wanita dewasa awal adalah pribadi yang sudah punya bentuk dan relatif stabil, sehingga individu mampu memilih apa yang ia kehendaki. Konsep diri pada wanita dewasa awal idealnya sudah terbentuk dan bersifat stabil, sehingga perilaku diluar pemikiran rasional seperti perilaku konsumtif jarang dilakukan.

Saran untuk penelitian selanjutnya yang perlu dicermati adalah mengenai pengambilan jumlah sampel yang memadai. Pada penelitian ini, walaupun jumlah subyek cukup banyak (385 responden), dengan jumlah akumulasi jawaban netral sebanyak 50.9\%, jumlah tersebut belum mampu melihat hipotesis penelitian dengan baik, dan jumlah 385 responden hanya mencakup sebagian kecil subyek dengan kategori wanita dewasa awal di Jakarta yang jumlahnya sangat banyak. Sehingga untuk penelitian selanjutnya, diharapkan jumlah subyek dapat ditambah lagi.

\section{Saran praktis}

Saran yang dapat diberikan kepada para wanita dewasa muda adalah terdapat hubungan antara konsep diri dan perilaku konsumtif, terutama pada aspek kebutuhan sekunder seperti kosmetik, sehingga dapat berguna sebagai refleksi dan antisipasi perilaku konsumtif pembelian kosmetik yang serupa. 


\section{Ucapan Terima Kasih}

Proses penyusunan penelitian ini tidak terlepas dari bimbingan dan bantuan dari berbagai pihak, baik secara langsung maupun tidak langsung. Terima kasih kepada pihak Universitas yang telah mendukung dalam penelitian ini.

\section{REFERENSI}

Admin. (2013). Indonesia lahan subur industry kosmetik. Diunduh dari http://kemenperin.go.id/artikel/5897/Indonesia-Lahan-Subur-Industri-Kosmetik

Ahman, E. (2007). Membina kompetensi ekonomi. Bandung: Grafindo Media Pratama.

Apollo. (2007). Hubungan antara konsep diri dengan kecemasan. Manasa, 1 (1), 19-21.

Astuti, E. D. (2013). Perilaku konsumtif dalam membeli barang pada ibu rumah tangga di kota Samarinda. eJournal Psikologi, 1 (2), 148-156.

Becker, H. S. (1964). Personal change in adult life. Sociometry, 27(1), 40-53.

Cannon, J. P., Perreault, W. D., \& McCarthy, J. (2008). Pemasaran dasar: Pendekatan manajerial global (16 $6^{\text {th }}$ ed.). Jakarta: Penerbit Salemba.

Corr, C. A., Nabe, C. M., \& Corr, D. M. (2009). Death and dying, life and living (6 $6^{\text {th }}$ ed.). Belmont, CA: Wadsworth Cengage Learning.

Fazriyanti, W. (2012). Pilihan produk kecantikan bergantung usia. Diunduh dari http://female.kompas.com/read/2012/07/25/13220020/Pilihan.Produk.Kecantikan.Bergan tung.Usia

Feist, J., \& Feist, G. J. (2009). Theories of personality (7 $7^{\text {th }}$ ed.). New York: McGraw-Hill International.

G, S. (2014). Where beauty beats: Sephora Indonesia. Diunduh dari http://femaledaily.com/blog/2014/07/26/beauty-beats-sephora/

Hurlock, B. E. (1999). Psikologi perkembangan: Suatu pendekatan sepanjang rentan kehidupan. Jakarta: Erlangga.

Iswari, T. R. (2007). Buku pegangan ilmu pengetahuan kosmetik. Jakarta: Gramedia Pustaka Utama.

Kartono, K. (1992). Psikologi wanita: mengenal gadis remaja dan wanita dewasa. Bandung: Mandar Maju.

Keliat, B. A. (1992). Gangguan konsep diri. Jakarta: EGC.

Monks, F. J., Knoers, A. M. P., \& Haditono, S. R. (2001). Psikologi perkembangan: Pengantar dalam berbagai bagiannya. Yogyakarta: Gajah Mada University Press.

Papalia, D. E., Olds, S. W., \& Feldman, R. D. (2009). Human development (11 ${ }^{\text {th }}$ ed.). New York: McGraw-Hill International.

Pertiwi. (1989). Masalah 89-95. Jakarta: Yayasan Gema Pratasa.

Potter, P. A. \& Perry, A. G. (2005). Buku ajar fundamental keperawatan: Konsep, proses \& praktek ( ${ }^{\text {th }}$ ed.). Jakarta : EGC.

Prasetijo, R. \& Ihalauw, J. (2005). Perilaku konsumen. Yogyakarta: Andi Offset.

Purbasari, C., \& Kartasamita, S. (2008). Konsep diri wanita berpacaran. Arkhe, 13 (2), 90-91.

Puspasari, A. (2007). Mengukur konsep diri anak. Jakarta: PT Elex Media Komputindo.

Rakhmat, J. (2005). Psikologi komunikasi (edisi revisi). Jakarta: Gramedia.

Rostanti, Q. (2013, September 24). Pasar kosmetik Indonesia sangat menjanjikan.Republika. Diunduh dari http://www.republika.co.id/berita/ekonomi/ritel/13/09/24/mtmbg0-pasarkosmetik-di-indonesia-sangat-menjanjikan

Schiffman, L. G. \& Kanuk, L. L. (2009). Consumer behavior (10 th ed.). New Jersey, UK: Pretince Hall.

Setiadi, N. J. (2003). Perilaku konsumen. Jakarta: Kencana Prenanda Media. 
Stuart, G. W. \& Sundeen, S. J. Keperawatan jiwa (3 ${ }^{\text {rd }}$ ed.). Jakarta: EGC.

Sugiyono. (2007). Metode penelitian pedidikan pendekatan kuantitatif, kualitatif, dan R\&D. Bandung: Alfabeta.

Sumartono. (2002). Terperangkap dalam iklan. Bandung: CV Alfabeta.

Sumarwan, U. (2013). Konsep diri ideal konsumen perempuan dan makna simbolik produk kecantikan. Jakarta: PT Kartini Cahaya Lestari

Tambunan, T. (2001). Perekonomian Indonesia: Teori dan temuan empiris. Jakarta: Ghalia Indonesia.

Ustadiyanto, R. \& Ariani, S. R. (2002). Strategi serangan internet marketing (2 ${ }^{\text {nd }}$ ed.). Yogyakarta: Andi.

White, L. E., Duncan, G., \& Baumle, W. (2011). Foundations of basic nursing (3 ${ }^{\text {rd }}$ ed.). Boston: Cengage Learning.

Wong, D. L., Hockenberry-Eaton, M., Wilson, D., Winkelstein, M. L., \& Schwartz, P. (2002). Buku ajar keperawatan pediatrik wong $\left(6^{\text {th }}\right.$ ed.). Jakarta: Penerbit Buku Keperawatan EGC. 